\title{
ANALIZA WŁASNOŚCI AERODYNAMICZNYCH PROFILU NACA 0018 W ZAKRESIE MAEYCH LICZB REYNOLDSA
}

\author{
Bartosz Kątski, Krzysztof Rogowski \\ Politechnika Warszawska, Instytut Techniki Lotniczej i Mechaniki Stosowanej, Warszawa \\ e-mail: krogowski@meil.pw.edu.pl
}

\begin{abstract}
W pracy przedstawiono rezultaty badań numerycznych profilu aerodynamicznego NACA 0018 w zakresie małych liczb Reynoldsa od 10000 do 1 mln oraz w zakresie katów natarcia od $0^{\circ}$ do $20^{\circ}$. Wyniki zaprezentowano w postaci charakterystyk współczynników siły nośnej i oporu w funkcji kąta natarcia. Badania przeprowadzono, wykorzystując model turbulencji k- $\omega$ SST oraz hybrydową siatkę obliczeniową złożoną z siatki strukturalnej w pobliżu krawędzi profilu oraz siatkę niestrukturalną w pozostałym obszarze domeny obliczeniowej. Intencją autorów pracy było pokazanie możliwości zastosowania podejścia numerycznego w badaniach profili w zakresie małych liczb Reynoldsa. Przeprowadzone badania pokazały, że minimalna liczba Reynoldsa, przy której wartość błędu jest akceptowalna, wynosi 40000 . Rezultaty badań symulacyjnych sił aerodynamicznych przedstawiono również tabelarycznie do wykorzystania w innych analizach.
\end{abstract}

\section{Wstęp}

Amerykański komitet doradczy do spraw aeronautyki (National Advisory Committee for Aeronautics), przeniesiony później do nowopowstałej NASA. jako jeden z pierwszych opracował rodzinę czterocyfrowych profili aerodynamicznych. Kształt profilu opisany jest za pomoca czterech cyfr umieszczonych po słowie NACA. Pierwsza cyfra definiuje maksymalne ugięcie linii szkieletowej wyrażone w procentach, druga cyfra określa położenie strzałki ugięcia w procentach długości cięciwy począwszy od noska profilu. Dwie ostatnie cyfry określają maksymalną grubość profilu wyrażoną w procentach długości cięciwy [1], [2]. Profile symetryczne określone są jedynie za pomocą dwóch ostatnich cyfr NACA 00XX. Kształt profilu można zdefiniować za pomocac wzoru [3]

$$
y_{t}=5 t\left(0,2969 \sqrt{x}-0,1260 x-0,3516 x^{2}+0,2843 x^{3}-0,1015 x^{4}\right)
$$

gdzie: $x$ - współrzędna określająca położenie wzdłuż cięciwy odniesiona do długości cięciwy, $y_{t}$ - współrzędna określająca grubość profilu w punkcie określonym przez współrzędną $x$, $t$ - maksymalna grubość cięciwy odniesiona do długości cięciwy.

Charakterystyki aerodynamiczne czterocyfrowych profili serii NACA badane były już w latach 30. ubiegłego stulecia. Jacobs i in. [4] opublikowali raport zawierający współczynniki siły nośnej oraz oporu szeregu profili serii NACA badanych dla liczby Reynoldsa $3 \mathrm{mln}$. Wyniki badań tunelowych profili czterocyfrowych dla liczb Reynoldsa w zakresie od $3 \mathrm{mln}$ do $6 \mathrm{mln}$ opublikowano w raporcie [5].

Czterocyfrowe symetryczne profile lotnicze serii NACA są bardzo często wykorzystywane przy projektowaniu wirników siłowni wiatrowych typu Darrieusa. Liczby Reynoldsa łopat tego rodzaju wirników są jednak dużo mniejsze w porównaniu z „lotniczymi”. Niewielkie wirniki o średnicy $1 \mathrm{~m}$ pracuja przy średniej licznie Reynoldsa na poziomie od 40 tys. do 170 tys. [6]-[8]. W przypadku większych wirników o średnicy $17 \mathrm{~m}$ liczba Reynoldsa dochodzi do $3 \mathrm{mln}$ [9]. Do dziś jedynym dostępnym źródłem zawierającym charakterystyki aerodynamiczne profili 
w szerokim zakresie liczb Reynoldsa od 10 tys. do 10 mln jest raport Sheldahla i Klimasa [10]. Oczywiście dostępne są również wyniki innych badań dotyczących profili NACA XXXX, są one jednak ograniczone np. do jednego profilu czy też do jednej liczby Reynoldsa [11].

W badaniach osiągów aerodynamicznych wirników siłowni wiatrowych Darrieusa wykorzystuje się metody numeryczne dynamiki płynów. Opływ tego rodzaju wirnika jest bardzo złożony i zwykle nie może być rozważany jako stacjonarny. Dodatkowo geometria wirnika bardzo utrudnia opracowanie siatki strukturalnej w jego otoczeniu [7]. Dlatego zazwyczaj stosowana bywa siatka obliczeniowa hybrydowa złożona z siatki strukturalnej w pobliżu krawędzi łopat oraz siatki niestrukturalnej w pozostałym obszarze [12]. Dotychczasowe badania potwierdzają również dużą skuteczność modelu turbulencji k- $\omega$ SST. Pozwala on na otrzymanie wiarygodnych rezultatów badań symulacyjnych łopat wirnika. Obliczenia prowadzone z wykorzystaniem tego modelu są z reguły stabilne.

Symulacje opływu profilu NACA 0018 z wykorzystaniem programu ANSYS CFX przeprowadzili między innymi Wiklak i Smolny [13]. Obliczenia te obejmowały liczby Reynoldsa w zakresie od $1,5 \cdot 10^{5}$ do $10^{6}$. Hassan i in. [14] badali profil NACA $0018 \mathrm{w}$ zakresie liczb Reynoldsa od 300000 do 1000000 oraz w zakresie kątów natarcia od $0^{\circ}$ do $25^{\circ}$. Symulacje przeprowadzone przez Wiklaka i Smolnego wykonane były dla wąskiego zakresu liczb Reynoldsa, natomiast badania Hassana i in. przeprowadzono, stosując siatkę strukturalną w całej domenie obliczeniowej.

Celem tej pracy jest pokazanie, w jaki sposób dwurównaniowy model turbulencji k- $\omega$ SST oraz siatka hybrydowa radzą sobie z wyznaczeniem charakterystyk aerodynamicznych profilu aerodynamicznego NACA 0018 w szerokim zakresie małych liczb Reynoldsa w przedziale od $10^{4}$ do $10^{7}$.

\section{Model numeryczny}

Badania numeryczne przeprowadzono dla symetrycznego profilu aerodynamicznego NACA 0018 o długości cięciwy $1 \mathrm{~m}$. Do obliczeń wykorzystano domenę obliczeniową w kształcie litery C o wymiarach podanych na rys. 1. Domena obliczeniowa o takich parametrach nie wpływa na rezultaty numeryczne sił aerodynamicznych [14].

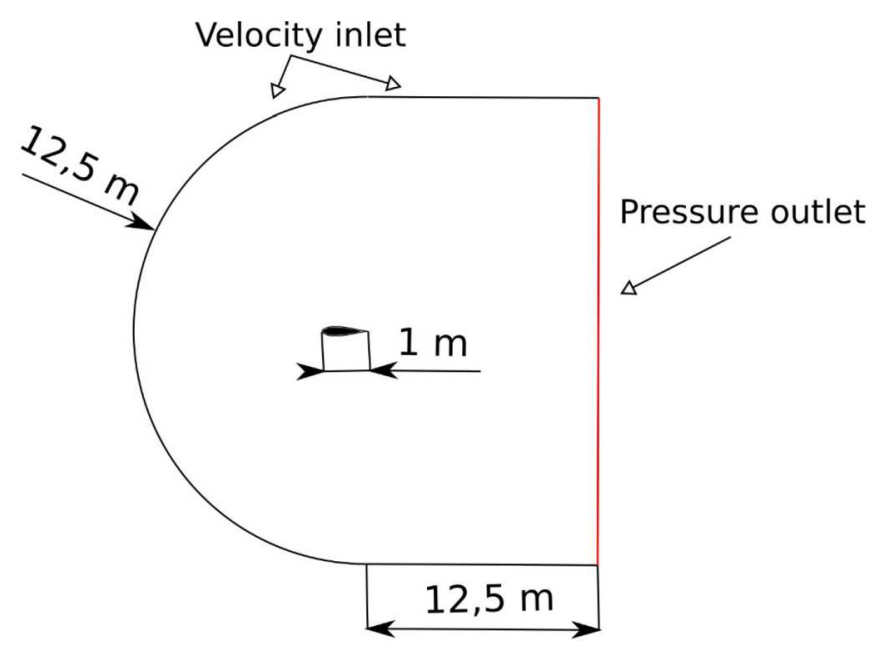

Rys. 1. Domena obliczeniowa

Siatka obliczeniowa złożona jest z siatki strukturalnej w pobliżu krawędzi profilu oraz z siatki niestrukturalnej w pozostałym obszarze. Obwód profilu podzielono na 150 elementów o jednakowej długości. Siatka strukturalna złożona jest ze 100 warstw, zaś tempo wzrostu warstw siatki strukturalnej wynosi 1,1. Grubość pierwszej warstwy siatki strukturalnej wynosiła $2,3 \cdot 10^{5} \mathrm{~m}$. 
Taka grubość pierwszej warstwy siatki umożliwiała utrzymywanie parametru wall y+ na poziomie $\leqslant 1$. Liczba elementów siatki o podanych parametrach wynosi 18 tys. elementów (rys. 2). Szczegółową analizę wrażliwości współczynników sił aerodynamicznych ze względu na zagęszczenie elementów siatki przedstawiono w pracy [15].

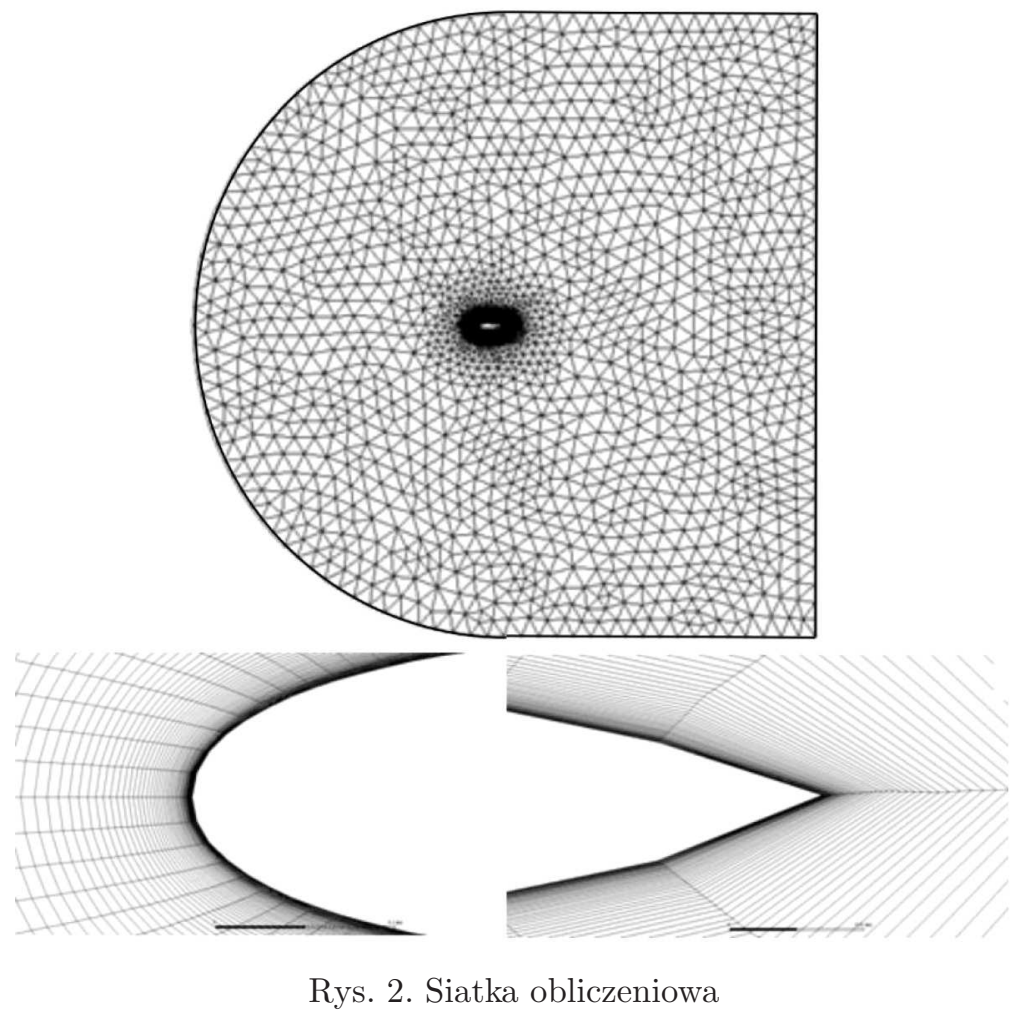

Obliczenia współczynników sił aerodynamicznych profilu NACA 0018 przeprowadzono dla szeregu kątów natarcia w zakresie od 0 do 20 stopni z krokiem równym $1^{\circ}$. Dla każdego kąta natarcia profil obracany był względem domeny obliczeniowej i dla danego położenia generowana była nowa siatka.

$\mathrm{Na}$ krawędziach domeny obliczeniowej nadano warunki brzegowe: velocity inlet oraz pressure outlet (rys. 1), zaś na krawędziach profilu zadany był warunek wall. Na wlocie założono intensywność turbulencji równą $0,5 \%$ oraz skali turbulencji $0,001 \mathrm{~m}$.

Do analizy numerycznej wybrano model turbulencji k- $\omega$ SST (ang. shear stress transport), który do układu uśrednionych równań Naviera-Stokesa wprowadza dwa dodatkowe równania transportu, jedno dla energii kinetycznej turbulencji oraz jedno dla stopnia jej dyssypacji. Model turbulencji k- $\omega$ SST wybrano ze względu na stosunkowo dokładne odwzorowywanie turbulencji w warstwie przyściennej, jak również na małą czułość na warunki brzegowe turbulencji na wlocie.

Rezultaty numeryczne współczynników sił aerodynamicznych porównano z eksperymentem Sheldahla i Klimasa [10].

\section{Rezultaty analiz aerodynamicznych przedstawione w postaci charakterystyk aerodynamicznych}

Na rysunkach 3-5 przedstawiono współczynniki sił aerodynamicznych dla profilu NACA 0018 dla trzech przykładowych liczb Reynoldsa w zakresie kątów natarcia od $0^{\circ}$ do $20^{\circ}$. Rezultaty pokazują, że wraz ze wzrostem liczby Reynoldsa wzrasta dokładność rozwiązania numerycznego. W przypadku najmniejszej z badanych liczb Reynoldsa (10 tys.) współczynniki siły nośnej są zbieżne z eksperymentem jedynie w wąskim zakresie kątów natarcia. 

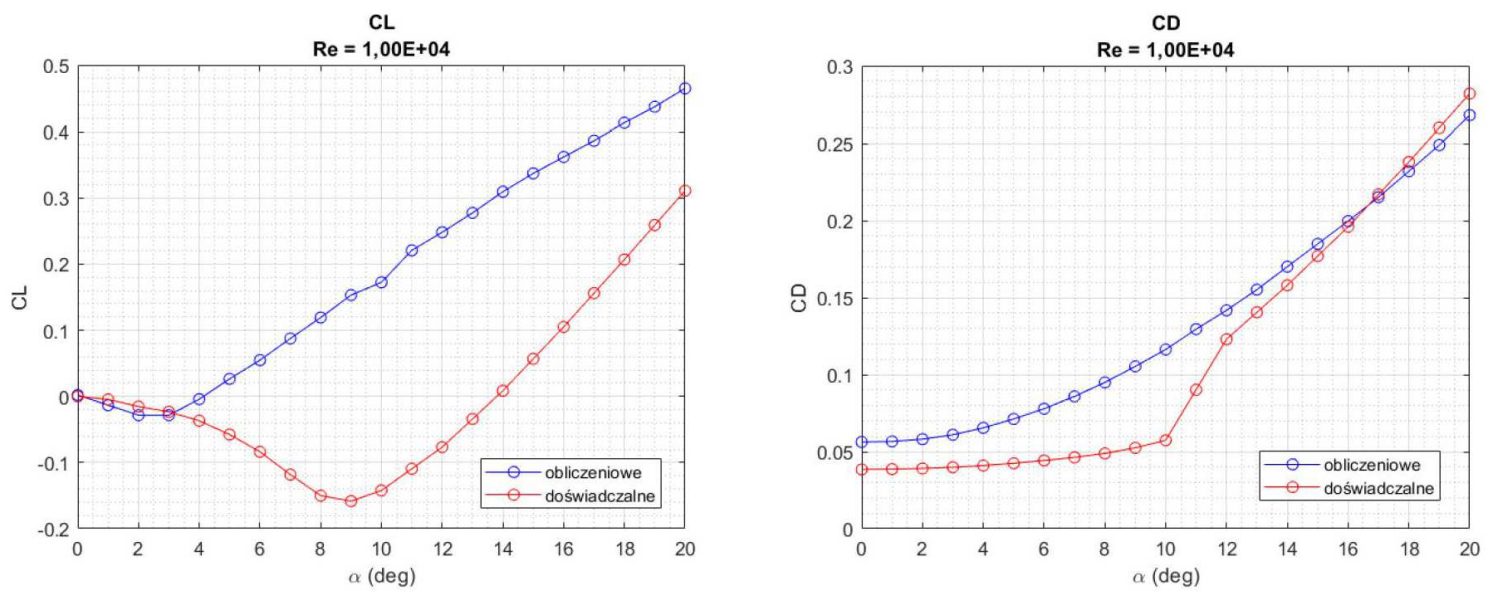

Rys. 3. Charakterystyki współczynnika siły nośnej oraz oporu dla profilu NACA 0018 dla liczby Reynoldsa 10 tys.
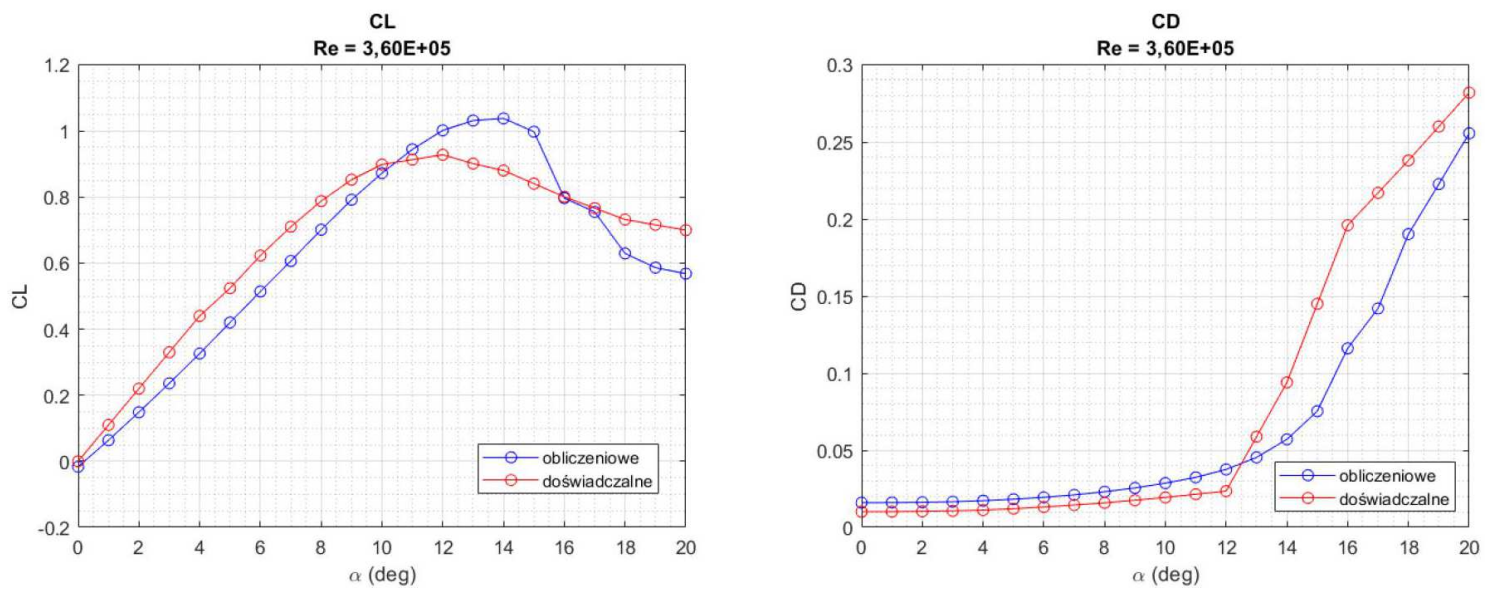

Rys. 4. Charakterystyki współczynnika siły nośnej oraz oporu dla profilu NACA 0018 dla liczby Reynoldsa 360 tys.
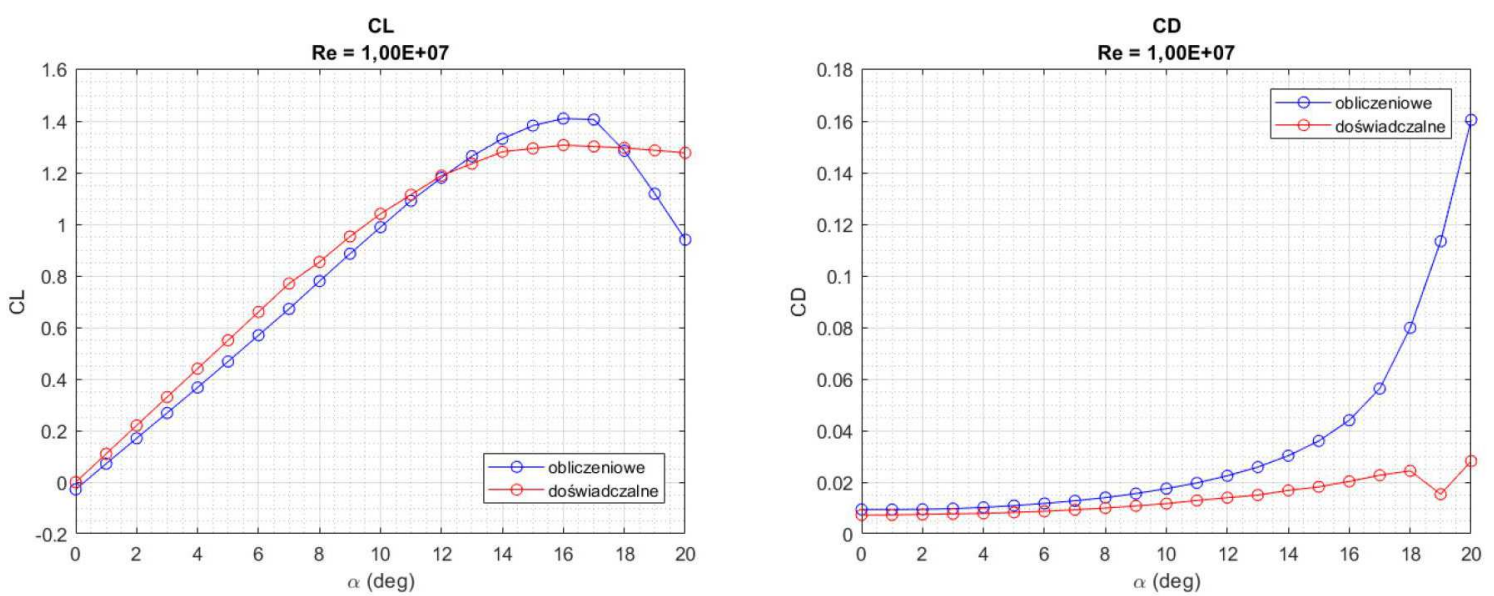

Rys. 5. Charakterystyki współczynnika siły nośnej oraz oporu dla profilu NACA 0018 dla liczby Reynoldsa $1 \mathrm{mln}$ 
Rysunki 6 i 7 przedstawiają charakterystyki współczynników siły nośnej oraz oporu w całym badanym zakresie liczb Reynoldsa oraz w całym zakresie badanych kątów natarcia. Na rysunku 6 wyraźnie widać, że uzyskane rezultaty numeryczne współczynnika siły nośnej znacząco odbiegają od wyników eksperymentalnych dla najmniejszych badanych liczb Reynoldsa. Warto również zauważyć, że spadek siły nośnej po przekroczeniu krytycznego kąta natarcia jest gwałtowniejszy w przypadku rezultatów numerycznych. Ponadto, analizując wykresy współczynnika oporu, przedstawione na rysunku 7, można stwierdzić, że przyrost tego współczynnika w funkcji kąta natarcia jest większy w przypadku wyników numerycznych.

(a)

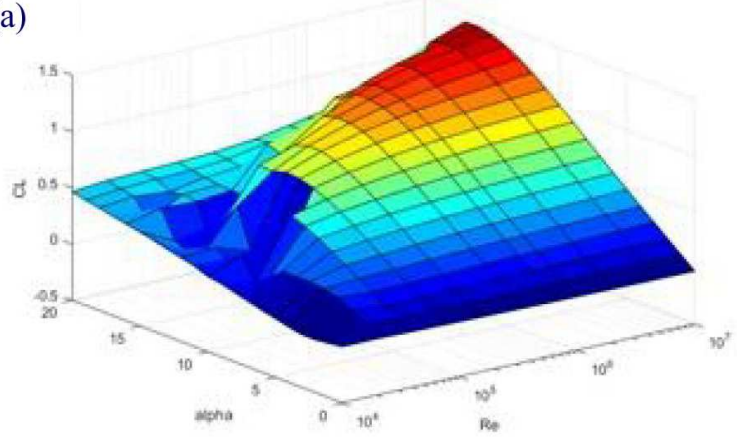

(b)

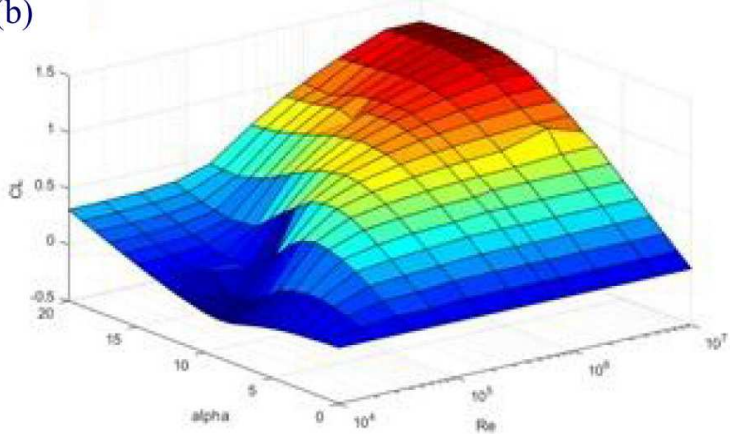

Rys. 6. Charakterystyki współczynnika siły nośnej w całym badanym przedziale liczb Reynoldsa oraz kątów natarcia: (a) rezultaty numeryczne, (b) rezultaty doświadczalne

(a)

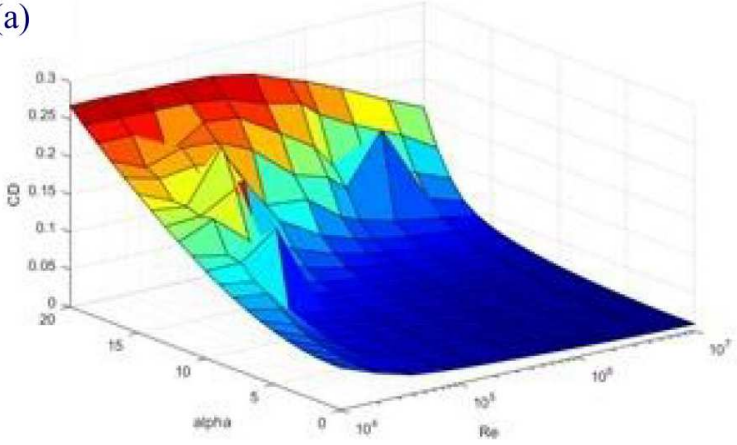

(b)

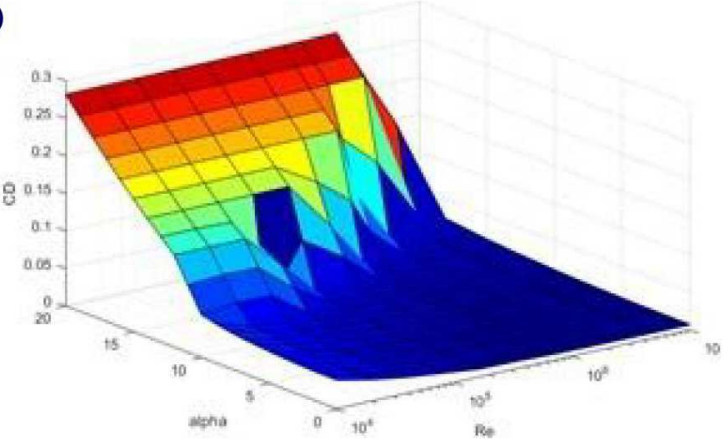

Rys. 7. Charakterystyki współczynnika oporu w całym badanym przedziale liczb Reynoldsa oraz kątów natarcia: (a) rezultaty numeryczne, (b) rezultaty doświadczalne

Aby porównać ze sobą współczynniki siły nośnej oraz oporu przedstawione na rysunkach 6 i 7, sporządzono wykresy błędów (rys. 8 i 9), które dla współczynnika siły nośnej oraz oporu zdefiniowano odpowiednio

$$
\begin{aligned}
& \delta C_{L}=\frac{\Delta C_{L}}{\left|C_{L \text { dośw }}\right|}=\frac{\left|C_{L \text { oblicz }}-C_{L \text { dośw }}\right|}{\left|C_{L \text { dośw }}\right|}[\%] \\
& \Delta C_{D}=\left|C_{D \text { oblicz }}-C_{D \text { dośw } w}\right|
\end{aligned}
$$

Na rys. 8 przedstawiono mapę błędu względnego $\delta C_{L}$. Dla większej przejrzystości zakres skali błędu ograniczono do $200 \%$. Warto zwrócić uwagę, że w niektórych miejscach wartość tego błędu jest wysoka, na co wpływ mają wartości odniesienia, które niekiedy są bliskie zeru (w szczególności dotyczy to małych kątów natarcia). Dla najmniejszych badanych liczb Reynoldsa wartość błędu względnego nie spada poniżej 50\%. Do oceny tego współczynnika, ze względu na liczne wystąpienia wartości współczynnika oporu bliskich zeru, wybrano definicję błędu bezwzględnego, r-nie $(3.1)_{2}$. Różnymi odcieniami koloru czerwonego oznaczono punkty, w których błąd 
przekraczał wartość 0,02. Największe błędy zaobserwowano w pobliżu krytycznego kąta natarcia. Podobnie jak w przypadku współczynnika siły nośnej, największe błędy zaobserwowano dla najmniejszych analizowanych liczb Reynoldsa. Dla liczb Reynoldsa powyżej 360000 występują coraz większe błędy w zakresie kątów $15^{\circ}-20^{\circ}$.

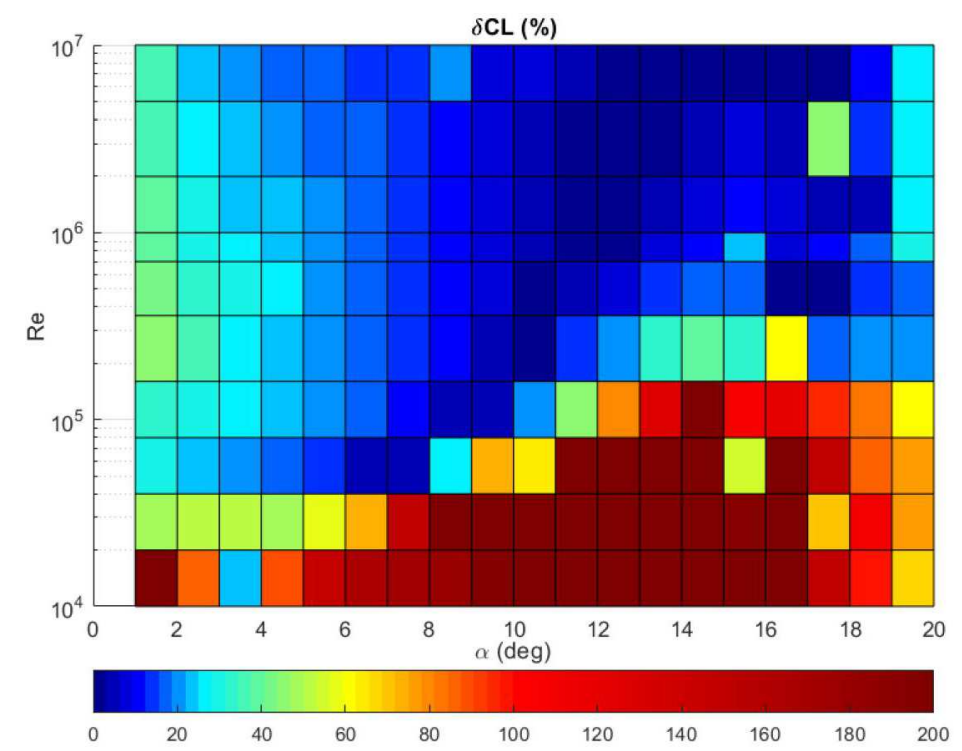

Rys. 8. Błąd względny $\delta C_{L}$

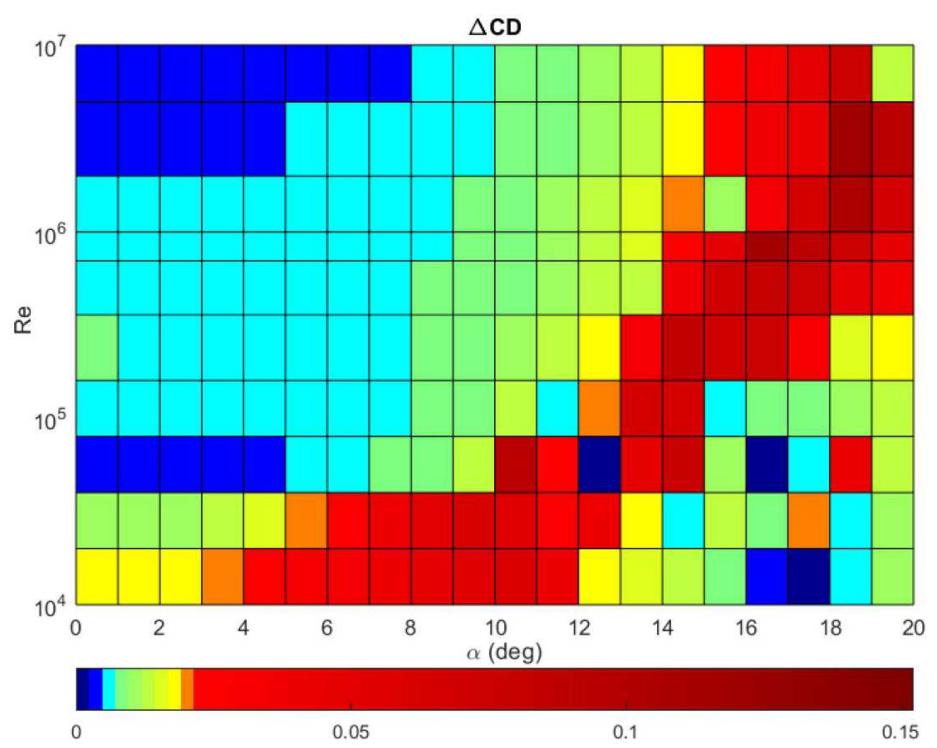

Rys. 9. Błąd bezwzględny $\Delta C_{D}$

\section{Podsumowanie}

Celem niniejszych badań była analiza charakterystyk współczynników aerodynamicznych profilu NACA 0018 w zakresie małych liczb Reynoldsa. Badania przeprowadzono, wykorzystując model turbulencji k- $\omega$ SST oraz hybrydową siatkę obliczeniową. Zamierzeniem autorów tej pracy było udowodnienie, do jakiego zakresu liczb Reynoldsa oraz do jakiego zakresu kątów natarcia prezentowana tu metoda daje akceptowalne rezultaty współczynników siły nośnej oraz oporu. Badania pokazały, że granicą stosowalności wykorzystanej metody jest liczba Reynoldsa 
40 000, natomiast zakres akceptowalnego kąta natarcia rośnie wraz ze wzrostem liczby Reynoldsa. W przypadku liczby Reynoldsa 40000 metoda daje akceptowalne rezultaty do kąta natarcia równego $8^{\circ}$, natomiast dla liczby Reynoldsa $1 \mathrm{mln}$ do kąta natarcia równego $14^{\circ}$.

Otrzymane rezultaty współczynników oporu są zgodnie z oczekiwaniem zawyżone. Wynika to bezpośrednio z zastosowanego podejścia - wyboru modelu turbulencji, który uwzględnia całą warstwę przyścienną jako turbulentną. Bardziej fizyczne rezultaty powinien w tym przypadku zapewnić model przejścia laminarno-turbulentnego. Analiza charakterystyk aerodynamicznych przy wykorzystaniu tego modelu turbulencji stanowi dalszy cel badań.

Wyniki przedstawione w tej pracy stanowią pierwszą próbę opracowania bazy danych charakterystyk współczynników aerodynamicznych siły nośnej i oporu dla profili symetrycznych serii NACA. Celem opracowania takiej bazy danych jest oszacowanie wrażliwości uproszczonych metod aerodynamicznych wykorzystywanych do wyznaczania sił aerodynamicznych łopat siłowni wiatrowych typu Darrieusa.

\section{Udział autorów}

Krzysztof Rogowski - autor tekstu całego artykułu; promotor pracy dyplomowej pana Kątskiego; pomysłodawca tematu pracy.

Bartosz Kątski - przeprowadził obliczenia numeryczne; wykonał większość rysunków zaprezentowanych w tym artykule; miał udział w przygotowaniu tego artykułu.

\section{Bibliografia}

1. Czapla T., Czajkowski T., Analiza aerodynamiczna skrzydeł lotniczych z zastosowaniem systemów CAE, Autobusy: Technika, Eksploatacja, Systemy Transportowe, 17, 12, 892-897, 2016

2. Dole C.E., Lewis J.E., Badick J.R., Johnson B.A., Flight Theory and Aerodynamics: A Practical Guide for Operational Safety, 3rd ed., Wiley, 2016

3. Moran J., An Introduction to Theoretical and Computational Aerodynamics, Dover 2010

4. Jacobs N.E., Ward K.E., Pinkerton R.M., The characteristics of 78 related airfoil sections from tests in the variable-density wind tunnel, National Advisory Committee for Aeronautics, Report No. 460, 1935

5. Abbott I.H., von Doenhoff A.E., Stivers L. JR., Summary of airfoil data, NACA TR-824, 1945

6. Rogowski K., Hansen M.O.L., Maroński R., Lichota P., Scale adaptive simulation model for the darrieus wind turbine, Journal of Physics: Conference Series, 753, 022050, 2016.

7. Bangga G., Dessoky A., Wu Z., Rogowski K., Hansen M.O.L., Accuracy and consistency of CFD and engineering models for simulating vertical axis wind turbine loads, Energy, 206, 118087, 2020

8. Rogowski K., CFD Computation of the H-Darrieus wind turbinethe impact of the rotating shaft on the rotor performance, Energies, 12, 13, 2019

9. Rogowski K., Hansen M.O.L., Bangga G., Performance analysis of a H-Darrieus wind turbine for a series of 4-digit NACA airfoils, Energies, 13, 12, 3196, 2020

10. Sheldahl, R.E., Klimas, P.C., Aerodynamic characteristics of seven symmetrical airfoil sections through 180-degree angle of attack for use in aerodynamic analysis of vertical axis wind turbines, Technical Report SAND80-2114, Sandia National Labs: Albuquerque, NM, USA, 1981

11. Rogowski K., Maroński R., Hansen M.O.L., Steady and unsteady analysis of NACA 0018 airfoil in vertical-axis wind turbine, Journal of Theoretical and Applied Mechanics, 51, 1, 203-212, 2018 
12. Rogowski K., Rogowska K., Velocity field around darrieus wind turbine rotor using actuator cell model and other CFD methods, Task Quarterly, 22, 3, 2018.

13. Wiklak P., Smolny A. Analiza opływu profilu turbiny wiatrowej przy małych liczbach Reynoldsa, Cieplne Maszyny Przepływowe - Zeszyty Naukowe. Cieplne Maszyny Przepływowe - Turbomachinery, Politechnika Łódzka, 144, 55-64, 2013

14. Hassan G.E., Hassan A., Youssef M.E., Numerical investigation of medium range re number aerodynamics characteristics for NACA0018 airfoil, CFD Letters, 6, 4, 2014

15. KĄTSKi B., Analiza profilu NACA0018 w zakresie małych liczb Reynoldsa z wykorzystaniem metod numerycznych mechaniki płynów, Praca dyplomowa inżynierska, Politechnika Warszawska, Instytut

Techniki Lotniczej i Mechaniki Stosowanej, Warszawa, 2020

\section{Dodatek A - Współczynniki siły nośnej}

\begin{tabular}{|c|c|c|c|c|c|c|c|c|c|c|c|}
\hline $\begin{array}{c}\alpha \\
{\left[{ }^{\circ}\right]}\end{array}$ & \multicolumn{10}{|c|}{ Liczba Reynoldsa Re } \\
\hline \hline 0 & 0,0021 & 0,0039 & $-0,0029$ & $-0,0081$ & $-0,0121$ & $-0,0164$ & $-0,0196$ & $-0,0211$ & $-0,0238$ & $-0,0265$ & $-0,0280$ \\
\hline 1 & $-0,0134$ & 0,0893 & 0,0655 & 0,0609 & 0,0616 & 0,0638 & 0,0664 & 0,0677 & 0,0697 & 0,0710 & 0,0718 \\
\hline 2 & $-0,0285$ & 0,1690 & 0,1382 & 0,1367 & 0,1419 & 0,1485 & 0,1543 & 0,1573 & 0,1625 & 0,1672 & 0,1703 \\
\hline 3 & $-0,0285$ & 0,2329 & 0,2118 & 0,2161 & 0,2259 & 0,2360 & 0,2437 & 0,2479 & 0,2554 & 0,2630 & 0,2682 \\
\hline 4 & $-0,0042$ & 0,2657 & 0,2840 & 0,2961 & 0,3113 & 0,3263 & 0,3360 & 0,3411 & 0,3502 & 0,3600 & 0,3670 \\
\hline 5 & 0,0265 & 0,2835 & 0,3586 & 0,3796 & 0,4004 & 0,4202 & 0,4329 & 0,4387 & 0,4493 & 0,4600 & 0,4679 \\
\hline 6 & 0,0548 & 0,2738 & 0,4325 & 0,4638 & 0,4900 & 0,5140 & 0,5298 & 0,5369 & 0,5491 & 0,5610 & 0,5696 \\
\hline 7 & 0,0875 & 0,2879 & 0,5031 & 0,5455 & 0,5777 & 0,6064 & 0,6248 & 0,6335 & 0,6481 & 0,6618 & 0,6717 \\
\hline 8 & 0,1192 & 0,1752 & 0,5672 & 0,6238 & 0,6648 & 0,7010 & 0,7240 & 0,7343 & 0,7519 & 0,7679 & 0,7794 \\
\hline 9 & 0,1532 & 0,0951 & 0,6155 & 0,6915 & 0,7459 & 0,7918 & 0,8206 & 0,8329 & 0,8538 & 0,8721 & 0,8855 \\
\hline 10 & 0,1725 & 0,2903 & 0,0753 & 0,7452 & 0,8137 & 0,8723 & 0,9087 & 0,9248 & 0,9511 & 0,9728 & 0,9886 \\
\hline 11 & 0,2208 & 0,1946 & 0,1134 & 0,7816 & 0,8714 & 0,9443 & 0,9897 & 1,0097 & 1,0413 & 1,0695 & 1,0906 \\
\hline 12 & 0,2482 & 0,2646 & 0,1633 & 0,7940 & 0,9098 & 1,0017 & 1,0565 & 1,0814 & 1,1201 & 1,1542 & 1,1803 \\
\hline 13 & 0,2775 & 0,1462 & 0,5166 & 0,7570 & 0,9112 & 1,0315 & 1,1043 & 1,1358 & 1,1850 & 1,2297 & 1,2635 \\
\hline 14 & 0,3096 & 0,1266 & 0,3400 & 0,7638 & 0,8717 & 1,0380 & 1,1300 & 1,1717 & 1,2327 & 1,2874 & 1,3313 \\
\hline 15 & 0,3372 & 0,1884 & 0,1374 & 0,4443 & 0,7479 & 0,9978 & 1,1287 & 1,1816 & 1,2580 & 1,3282 & 1,3822 \\
\hline 16 & 0,3620 & 0,4305 & 0,4203 & 0,4487 & 0,7888 & 0,7967 & 1,0486 & 1,1280 & 1,2395 & 1,3338 & 1,4098 \\
\hline 17 & 0,3865 & 0,2733 & 0,4383 & 0,4555 & 0,5351 & 0,7549 & 0,8238 & 0,9661 & 0,6279 & 1,2910 & 1,4057 \\
\hline 18 & 0,4130 & 0,4471 & 0,4145 & 0,4744 & 0,5013 & 0,6292 & 0,7537 & 0,9217 & 0,9819 & 1,1432 & 1,2848 \\
\hline 19 & 0,4370 & 0,4654 & 0,4821 & 0,4930 & 0,5175 & 0,5862 & 0,6207 & 0,7055 & 0,8137 & 0,9563 & 1,1182 \\
\hline 20 & 0,4648 & 0,4939 & 0,5071 & 0,5176 & 0,5333 & 0,5680 & 0,6227 & 0,6531 & 0,7255 & 0,8549 & 0,9400 \\
\hline
\end{tabular}




\section{Dodatek B - Współczynniki oporu}

\begin{tabular}{|c|c|c|c|c|c|c|c|c|c|c|c|}
\hline \multirow{2}{*}{$\begin{array}{c}\alpha \\
{\left[{ }^{\circ}\right]}\end{array}$} & $1,0 \mathrm{E}+4$ & $2,0 \mathrm{E}+4$ & $4,0 \mathrm{E}+4$ & $8,0 \mathrm{E}+4$ & $1,6 \mathrm{E}+5$ & $3,6 \mathrm{E}+5$ & $7,0 \mathrm{E}+5$ & $1,0 \mathrm{E}+6$ & $2,0 \mathrm{E}+6$ & $5,0 \mathrm{E}+6$ & $1,0 \mathrm{E}+7$ \\
\hline \hline 0 & 0,0563 & 0,0389 & 0,0260 & 0,0214 & 0,0186 & 0,0160 & 0,0142 & 0,0133 & 0,0117 & 0,0102 & 0,0094 \\
\hline 1 & 0,0566 & 0,0394 & 0,0261 & 0,0215 & 0,0187 & 0,0161 & 0,0142 & 0,0134 & 0,0118 & 0,0102 & 0,0094 \\
\hline 2 & 0,0581 & 0,0406 & 0,0264 & 0,0217 & 0,0189 & 0,0163 & 0,0144 & 0,0135 & 0,0119 & 0,0103 & 0,0095 \\
\hline 3 & 0,0610 & 0,0428 & 0,0271 & 0,0222 & 0,0193 & 0,0166 & 0,0147 & 0,0138 & 0,0122 & 0,0106 & 0,0098 \\
\hline 4 & 0,0655 & 0,0473 & 0,0282 & 0,0231 & 0,0201 & 0,0173 & 0,0153 & 0,0143 & 0,0127 & 0,0111 & 0,0102 \\
\hline 5 & 0,0712 & 0,0530 & 0,0300 & 0,0245 & 0,0212 & 0,0183 & 0,0162 & 0,0152 & 0,0135 & 0,0118 & 0,0109 \\
\hline 6 & 0,0779 & 0,0617 & 0,0323 & 0,0263 & 0,0227 & 0,0195 & 0,0173 & 0,0162 & 0,0144 & 0,0127 & 0,0118 \\
\hline 7 & 0,0859 & 0,0758 & 0,0354 & 0,0287 & 0,0247 & 0,0211 & 0,0187 & 0,0176 & 0,0157 & 0,0139 & 0,0128 \\
\hline 8 & 0,0950 & 0,0898 & 0,0394 & 0,0317 & 0,0272 & 0,0231 & 0,0205 & 0,0192 & 0,0171 & 0,0152 & 0,0140 \\
\hline 9 & 0,1053 & 0,0990 & 0,0448 & 0,0355 & 0,0302 & 0,0256 & 0,0226 & 0,0212 & 0,0190 & 0,0169 & 0,0156 \\
\hline 10 & 0,1163 & 0,1176 & 0,1524 & 0,0407 & 0,0340 & 0,0287 & 0,0253 & 0,0238 & 0,0213 & 0,0191 & 0,0175 \\
\hline 11 & 0,1295 & 0,1204 & 0,1147 & 0,0480 & 0,0390 & 0,0324 & 0,0285 & 0,0268 & 0,0240 & 0,0215 & 0,0197 \\
\hline 12 & 0,1417 & 0,1613 & 0,1222 & 0,0588 & 0,0462 & 0,0376 & 0,0328 & 0,0307 & 0,0275 & 0,0247 & 0,0225 \\
\hline 13 & 0,1552 & 0,1585 & 0,1849 & 0,0770 & 0,0580 & 0,0454 & 0,0387 & 0,0360 & 0,0319 & 0,0285 & 0,0258 \\
\hline 14 & 0,1701 & 0,1642 & 0,2344 & 0,0927 & 0,0767 & 0,0571 & 0,0474 & 0,0436 & 0,0382 & 0,0337 & 0,0303 \\
\hline 15 & 0,1849 & 0,1649 & 0,1659 & 0,1705 & 0,1073 & 0,0754 & 0,0604 & 0,0548 & 0,0470 & 0,0407 & 0,0360 \\
\hline 16 & 0,1996 & 0,1877 & 0,1944 & 0,1884 & 0,1208 & 0,1162 & 0,0825 & 0,0733 & 0,0609 & 0,0511 & 0,0440 \\
\hline 17 & 0,2152 & 0,1959 & 0,2113 & 0,2084 & 0,1873 & 0,1420 & 0,1287 & 0,1085 & 0,1757 & 0,0703 & 0,0563 \\
\hline 18 & 0,2320 & 0,2320 & 0,1966 & 0,2281 & 0,2235 & 0,1902 & 0,1620 & 0,1323 & 0,1195 & 0,0980 & 0,0798 \\
\hline 19 & 0,2490 & 0,2485 & 0,2472 & 0,2466 & 0,2421 & 0,2227 & 0,2134 & 0,1928 & 0,1684 & 0,1410 & 0,1134 \\
\hline 20 & 0,2680 & 0,2687 & 0,2671 & 0,2667 & 0,2652 & 0,2556 & 0,2385 & 0,2304 & 0,2100 & 0,1804 & 0,1604 \\
\hline
\end{tabular}

\section{Analysis of aerodynamic properties of the NACA 0018 airfoil in a low Reynolds number range}

This paper presents results of numerical analysis of the NACA 0018 airfoil in the range of low Reynolds numbers from $1 \cdot 10^{4}$ to $1 \cdot 10^{6}$ and in the range of angles of attack from $0^{\circ}$ to $20^{\circ}$. The results are presented as characteristics of lift and drag coefficients in a function of the angle of attack. The research was carried out using the k- $\omega$ SST turbulence model and a hybrid computational mesh composed of a structural mesh near the airfoil edge and a non-structural mesh in the remaining area. The authors wanted to show the possibilities of using the numerical approach for analysis of airfoils at low Reynolds numbers. The conducted research showed that the minimum Reynolds number for which the numerical error value was acceptable was 40000 . The results of the numerical experiments of the aerodynamic forces are also presented in a tabular form for use in other analyzes. 